\title{
GENERATION Z: DECISION-MAKING PROCESS OF CAREER CHOICE
}

\author{
Blandína Šramová \\ Tomas Bata University, Zlín (Czech Republic)
}

\begin{abstract}
Purpose: Current adolescents (the Generation Z) are a generation who decides whether they will continue to study at the university after graduating from high schools and which university they will choose. This decision process carries long-lasting consequences for personality as well as for society. It influences their life satisfaction, the realization of potential in the future and social acceptance. Both explicit and implicit factors are involved in the decision-making process of Generation $\mathrm{Z}$.

Key points: The aim of study is to reveal the key factors in the decision-making process of the Generation $\mathrm{Z}$ on the basis of existing theories describing human functioning. These are the basis for explaining career choices and career development. While psychologically oriented career studies emphasize personality predispositions, values or self-concepts, sociological studies are more oriented to prestige, the choice of occupation in terms of socio-economic hierarchy and social structure of society.

Methodology: In this study, theoretical analyses will be used.
\end{abstract}

Keywords: Generation Z, career choice, decision-making process.

\section{Introduction}

The adolescents who currently represent a Generation Z (born after the mid-1990s) are the generation who decides whether or not to study at university after high school and - if they go - which university and what field of study they will choose. This decision-making process is complicated (Germeijs et al., 2006) and carries long-lasting consequences for both individuals (life satisfaction, realization of personality potential in the future, social acceptance; Mann, Harmoni, \& Power, 1989) and society (usability of the individual in the labour market according to current needs and long-term plans of the society). Both explicit/objective, and implicit/subjective factors are involved in the selection of the Generation $\mathrm{Z}$ professions. Explicit factors can be defined on the basis of quantitative or qualitative research methods. But many times the implicit factors play a major role in decision making. However, we know little about the Czech Generation Z, which is already beginning to enter the labor market and will soon be a significant force here. There is only partial research focused on some areas of their lives, e.g. identity, motivation preferences, gamification, branding, shopping behaviour (Macek et al., 2002; Šramová, Džupina, \& Jurášková, 2013; Černíková, Šmahel, \& Wright, 2018; Šramová, \& Pavelka, 2019). The choice of profession represents one of the most important decision-making processes and at the same time an extremely complicated task that secondary school students have to solve (Hlad'o, \& Drahoňovská, 2012). PR and the presentation of universities in the open days, higher education fairs, printed promotional materials, websites, social networks, etc. also play important roles in the decision-making process of high school students. However, there is a lack of research carried out on a representative sample of contemporary adolescents (Generation Z) which would examine decision-making factors and processes, whether to study or not at universities comprehensively, and when deciding to go further on, would examine the factors and processes associated with the selection of specific fields of study and future professions. The research also lacks the emphasis on the interdisciplinary synergy of research disciplines, which are essential for the complex involvement of the phenomena and processes in question, especially psychology, cognitive psychology, pedagogy, sociology, marketing, media studies, social policy, and behavioral economics. Therefore, it is important to know the decision-making process of career choices as the basis for research.

\section{Models of the decision-making process and the career decision-making process}

Classical models of decision making are based on mathematical models of human behavior. These models are based on the premise that people who make decisions are (Slovic, 1995; Sternberg, 
1999): 1/ informed about all possible alternative decisions and their consequences; $2 /$ sensitive to the subtle differences among the alternatives; $3 /$ rational. The fundamental shift in the concept of judgment and decision-making was brought about by the collaboration of Tversky and Kahneman, which led to the construction of the behavioral economy concept (Thaler, 2017). Kahneman and Tversky accentuated the fact that man much more likely makes decisions based on concise reasoning, prejudices, and heuristics than rational reasoning. On the one hand, these procedures facilitate cognitive processes in decision making, but they also cause greater error rates and weaken the ability to make decisions effectively. The heuristics of representativeness, availability, illusory correlation, anchorage, and adaptation can be a good example (Kahneman, \& Tversky, 1990; Tversky, \& Kahneman, 1981; Thaler, 2017).

The crucial and decisive categories in the taxonomy of a career decision-making process are those that try to uncover decision-making difficulties (Gatti, \& Saka, 2001). According to the authors, these are: 1/ lack of preparedness associated with a) motivation, b) indecision, and c) mistrust; $2 /$ lack of information about a) the decision-making process in career choice, b) about the person himself/herself, c) about the alternatives, and d) the ways of getting information, and finally; 3 / inconsistent information regarding a) unreliable information, b) internal conflicts, and c) external conflicts.

Several papers suggest that adolescents consider the consequences of their potentially risky behavior to be less risky in comparison with the adult populations (Beyth-Marom et al., 1993). This also corresponds to the triadic model of motivated behavior of adolescents, which is based on the assumption that motivated behavior is the result of three behavioral or neural systems (Ernst, Pine, \& Hardin, 2006): $1 /$ reward-driven system; 2 / harm-avoidant system; 3 / system of regulators.

Modern theories of career choice and development are based on the premise already mentioned by Parsons (1909) and they emphasize the active involvement of the individual in the career decision-making (Holland, 1997; Dawis, \& Lofquist, 1984; Super, Super, \& Savickas, 1996). Active involvement results in individual satisfaction, low employer's costs, and increasing employment. The existing theories clarifying human behavior are becoming the basis for the selection and interpretation of a key career choice and career concepts. This is the case with the use and application of Rokeach's definition of values (Rokeach, 1973) by Brown's (Brown, \& Associates, 2002) or Bandura's social learning theory (Bandura, 1971) by Mitchell and Krumboltz (Mitchell, \& Krumboltz, 1996). There are four dominant theories in the academic sphere: 1/ Holland's theory of personality and vocational choices (Holland, 1997), 2/ Krumlotz's social leasing theory (Krumboltz, 1979) 3/ Super's developmental theory (Super, 1990) and 4/ Davis's \& Lofquist's work adjustment theory (Dawis, \& Lofquist, 1984). All the above-mentioned theories try to reveal predicted degrees of suitability or congruence of an individual's personality to his job and work. These theories initially underestimated the influence of the social environment on vocational choice. Only later did they start to attribute their role (Holland, 1997; Blustein, $\&$ Ellis, 2000). One of the significant contributions are the traditional works by Sewell and Hauser (1976) who laid the foundations for the model involving school results as well as the influence of parents, teachers, and friends on career choices. While psychological studies on career selection emphasize personality predispositions, values or self-concept, sociological studies emphasize prestige in terms of socio-economic hierarchy or social structure (Mortimer, 1996).

\section{Conclusion}

If we want to reveal the motivations, characteristics, and predictors determining the decision-making processes of adolescents in the choice of the Czech universities, we have to know about career decision making. Only then we can create a theoretical model that will enable the interpretation and prediction of the communication tools and channels leading the choices. To use the concepts of behavioral economics is a handful. In just realized research project we focus on a representative sample of the Czech adolescents. The aim of the research is directed through quantitative and qualitative methods to reveal decision-making factors and mechanisms in the processes of higher education choices in relation to the value orientations of the adolescents, major influencers of these processes (parents, teachers, career counsellors), and to the recruitment and image-maker communications and PR of universities.

\section{References}

Bandura, A. (1971). Social learning theory. Morristown, NJ: General Learning Press.

Beyth-Marom, R., Austin, L., Fischhoff, B., Palmgren, C., \& Jacobs-Quadrel, M. (1993). Perceived consequences of risky behaviors: adults and adolescents. Developmental Psychology, 29, 549-563. doi:10.1037/0012-1649.29.3.549 
Blustein, D. L., \& Ellis, M. V. (2000). The cultural context of career assessment. Journal of Career Assessment, 8, 379-390. doi:10.1177/106907270000800407

Černíková, M., Šmahel, D., \& Wright, M. F. (2018). Children's Experiences and Awareness about Impact of Digital Media on Health. Health Communication, 33 (6), 664-673. doi:10.1080/10410236.2017.1298197

Dawis, R. V., \& Lofquist, L. (1984). A psychological theory of work adjustment. Minneapolis: University of Minnesota.

Ernst, M., Pine, D. S., \& Hardin, M. (2006). Triadic model of the neurobiology of motivated behavior in adolescence. Psychol Med (36), 299-312. doi:10.1017/S0033291705005891

Gati, I., \& Saka, N. (2001). High school students' career-related decision-making difficulties. Journal of Counseling \& Development, 79 (3), 331-340. doi: 10.1002/j.1556-6676.2001.tb01978.x

Germeijs, V., Verschueren, K., \& Soenens, B. (2006). Indecisiveness and High School Students' Career Decision-Making. Process: Longitudinal Associations and the Mediational Role of Anxiety. Journal of Counseling Psychology, 53 (4), 397-410. doi:10.1037/0022-0167.53.4.397

Hlad'o, P., \& Drahoňovská, P. (2012). Rozhodováni žáků základních a středních škol o dalším studiu a práci v pohledu žáků $i$ jejich rodičů: Analýza vlivů sociálního okolí a využivání informačních zdrojů na základě dotazníkového šetření. Praha: MUV. Retrieved from http://www.nuov.cz/uploads/Vzdelavani_a_TP/KP_Volba_zaci_rodice_pro_www.pdf

Kahneman, D., \& Tversky, A. (1990). Prospect theory: An analysis of decision under risk. In P. K. Moser (Ed.), Rationality in action: Contemporary approaches (pp. 140-170). New York, NY, US: Cambridge University Press. (Reprinted from "Econometrica" 47 (1979), 263-91.)

Krumboltz, J. D. (1979). A social learning theory of career decision-making. In A. M. Mitchell, G. B. Jones, \& J. D. Krumboltz (Eds.), Social learning and career decision-making. Cranston, RI: Carroll Press.

Macek, P., Mareš, J., Ježek, S., \& Valášková, M. (2002). Současný výzkum adolescentů: východiska, soubor, metody. In V. Smékal, \& P. Macek (Eds.), Utváření a vývoj osobnosti. Psychologické, sociální a pedagogické aspekty (pp. 129-146). Brno: Barrister \& Principal.

Mann, L., Harmoni, R., \& Power, C. (1989). Adolescent decision-making: The development of competence. Journal of Adolescence, 12 (3), 265-278. doi:10.1016/0140-1971(89)90077-8

Mitchell, L. K., \& Krumboltz, J. D. (1996). Krumboltz's learning theory of career choice and counseling. In D. Brown, L. Brooks, \& Associates, Career choice and development (pp. 233-280). San Francisco: Jossey-Bass.

Mortimer, J. T. (1996). Social psychological aspects of achievement. In A. C. Kerckhoff (Ed.), Generating social stratification: Toward a new research agenda (pp. 17-36). Boulder, CO: Westview Press.

Parsons, F. (1909). Choosing a vocation. New York: Agathon Press.

Rokeach, M. (1973). The nature of human values. New York: Free Press.

Sewell, W. H., \& Hauser, R. M. (1976). Causes and consequences of higher education: Models of the status attainment process. In W. H. Sewell, R. M. Hauser, \& D. Featherman (Eds.), Schooling and achievement in American society (pp. 9-27). New York: Academic Press.

Slovic, P. (1995). The construction of preference. American Psychologist, 50 (5), 364-371. doi:10.1037/0003-066X.50.5.364

Slovic, P., \& Fischhoff, B. (1988). Decision making. In R. C. Atkinson, R. J. Herrnstein, G. Lindzey, \& R. D. Luce (Eds.), Stevens' handbook of experimental psychology: Perception and motivation; Learning and cognition (pp. 673-738). Oxford, England: John Wiley \& Sons.

Sternberg, R. J. (1999). The theory of successful intelligence. Review of General Psychology, 3, 292-316. doi:10.1177/026142940001500103

Super, D. E. (1990). A Life-span, Life-space Approach to Career Development. In Brown, D., Brooks, D. (Eds.). Career Choice and Development: Applying Contemporary Theories to Practice. (pp. 197-262). San Francisco, CA: Jossey-Bass.

Super, D. E., Super, C., \& Savickas, M. L. (1996). A life- span, lifespace approach to careers. In D. Brown, L. Brooks, \& Associates, Career choices and development (3rd ed.), (pp. 121-178). San Francisco: Jossey-Bass.

Šramová, B., Džupina, M., \& Jurášková, O. (2013). Impact of value structure on brand engagement depending on degree of self-esteem of adolescents. International Journal of Innovation and Applied Studies, 3, 931-940.

Šramová, B., \& Pavelka, J. (2019). Gender differences and wellbeing indicators tendencies in motivational structure of adolescent online shopping behavior. International Journal of Retail \& Distribution Managementnt. doi:10.1108/IJRDM-08-2017-0173

Thaler, R. H. (2017). Neočekávané chování, přiběh behaviorální ekonomie, Praha: Argo.

Tversky, A., \& Kahneman, D. (1981). The framing of decisions and the psychology of choice. Science, 211, 453-458. doi:10.1126/science.7455683 